\title{
The role of lockdowns and health policies for COVID-19 in Italy
}

\author{
Jaime A. Teixeira da Silva, ${ }^{1}$ Panagiotis Tsigaris ${ }^{2}$ \\ ${ }^{1}$ Independent researcher, Kagawa-ken, Japan; ${ }^{2}$ Department of Economics, Thompson Rivers University, Kamloops, British \\ Columbia, Canada
}

\begin{abstract}
In response to the coronavirus disease 2019 (COVID-19) pandemic, Italy initially flattened the curve after a stringent lockdown spanning from February 23 to early May but not without casualties, with 240,760 cases and 34,788 deaths on June 30, 2020. However, increasingly lax policies saw rising cases starting in August. Italy currently sits with 423,578 cases and 36,616 deaths (October 20, 2020). This retrospective observational study aimed to assess stringency policies related to nation-wide containment and closure, as well as health system instruments, to determine their potency. The first nationally implemented policy was on January 31, followed by a battery of strong restrictions imposed on February 22-23. The Stringency Index peaked at 93.5 on April 12. However, policies were relaxed following a flattening of the curve on May 4 when the Stringency Index went from 93.5 to 63.0. Italy's policies were essential to contain the spread of the virus initially, but the lax policies since the end of spring, especially related to school reopening, no stay-at-home and domestic travel restrictions, and reduced contact tracing, have now resurrected the COVID-19 pandemic.
\end{abstract}

\section{Introduction}

In Italy, the first hospital admission of a case of coronavirus disease 2019 (COVID-19), caused by the severe acute respiratory syndrome-related coronavirus 2, was on February 20, 2020, and the first indigenous

Correspondence: Jaime A. Teixeira da Silva, Independent researcher, P. O. Box 7, Miki-cho post office, Ikenobe 3011-2, Kagawa-ken, 761-0799, Japan.

E-mail: jaimetex@yahoo.com

Key words: Containment; health policy; respiratory disease; SARS-CoV-2 virus; stringency index.

Funding: this research did not receive any specific grant from funding agencies in the public, commercial, or not-for-profit sectors.

Contributions: the authors, who are co-corresponding authors, contributed equally to the intellectual discussion underlying this paper, literature exploration, data mining and analyses, writing, reviews, and editing, and accept responsibility for its content.

Conflict of interests: the authors declare no conflict of interests.

Received for publication: 3 September 2020.

Revision received: 23 October 2020.

Accepted for publication: 27 October 2020.

This work is licensed under a Creative Commons Attribution NonCommercial 4.0 License (CC BY-NC 4.0).

${ }^{\circ}$ Copyright: the Author(s), 2021

Licensee PAGEPress, Italy

Italian Journal of Medicine 2021; 15:1-6

doi:10.4081/itjm.2020.1366 case was on February 21 with a red zone instituted in 11 municipalities on February 22 starting with Codogno where the first COVID-19 cases were recorded, ${ }^{1}$ then extended on March 8 to all of Lombardy and 14 northern provinces. ${ }^{2}$ The highest number of daily cases was 6557 on March 22, a value gleaned from the John Hopkins University (JHU) website. ${ }^{3}$ Through the implementation of various health policy measures to contain the spread of COVID-19, which are discussed later in greater detail, the curve was gradually, but forcefully, flattened. Indeed, data from JHU reveal that Italy showed a documented decline in daily cases $(\sim 1900)$ by the end of April but that, by June 30, it had suffered 240,760 cases of infection and 34,788 deaths. Almost four months later, after having successfully flattened the curve, the pandemic has resurrected due to the relaxation of policies, and there are now 423,578 cases and 36,616 deaths (October 20, 2020).

Researchers in the first few months of the pandemic made some observations worth mentioning. Grossi et al. indicated that Italy became the country with the highest number of COVID-19 cases on February 21, and the highest death toll $(17,127)$ on April 7 , having performed 44,107 tests per million people in Veneto and about half that number in Lombardy, in which $85 \%$ of cases were mild or asymptomatic. ${ }^{4}$ Tests were based on real-time polymerase chain reaction. ${ }^{5}$ Giordano et al. showed how the estimated basic reproduction number $\left(R_{0}\right)$ was reduced from 2.38 on day 1 (February 20) to 1.60 on day 22 (March 13), when the nation-wide lockdown was announced, 0.99 on day 28 (March 19) and then 0.85 on day 38 (March 29), suggesting that social-distancing measures, population-wide testing and contact tracing policies and practices were initially effective. ${ }^{2}$ Very im- 
portantly, Giordano et al. predicted that if no changes to policies were made over 350 days, $0.06 \%$ of the population would die from COVID-19, or $0.12 \%$ if policies were lax, ${ }^{2}$ corresponding to approximately 36,000 and 72,000 people, respectively. Compounding these issues, Lazzerini and Putoto lamented several issues: difficult decisions on public health measures were taken without the support of official, real-time data being available for the public on key surveillance indicators, unofficial and sometimes conflicting data are circulating in the media, and the lack of clarity whether a homogeneous criterion for testing has been applied. ${ }^{1}$

Although the curve had not been entirely flattened, the number of cases tailed off until the end of July, suggesting that the lockdown measures were effective. ${ }^{6}$ However, Italy then relaxed the lockdown in place since January 31 , resulting in the reemergence of COVID-19, as demonstrated later on in this paper.

Financially, the International Monetary Fund projected in April a 9.1\% decline in the Italian economy for 2020, extending it further in October to a $10.6 \%$ decline, ${ }^{7,8}$ caused by the policies to contain COVID19. These will undoubtedly cause societal suffering as a result of unemployment and lack of income. ${ }^{9}$

\section{Methods of research}

This retrospective observational study aims to examine the impact of different policies to prevent or curb COVID-19 that were enacted nation-wide by the Italian Government and Health Ministry during the January 1 to October 13 period. All data were retrieved from the Oxford COVID-19 Government Response Tracker (OxCGRT) stringency index (SI) time series spreadsheet. ${ }^{10}$ The SI is a composite index constructed using eight sub-categories of policies related to containment and closure, and a public information campaign category. It attempts to measure the stringency of policies in terms of lockdowns to restrict people's actions. ${ }^{10}$ These policies, in addition to the testing and contact tracing health system instruments, were analyzed to determine their potency towards containing the spread of the virus. Containment and closure policies included school, public transportation, and workplace closures, restrictions on gathering, cancellation of public events, stay-at-home requirements, as well as domestic and international travel controls (Table 1). A retrospective observational approach was used to detect any association between daily COVID19 cases and the above-listed policies.

This research did not explore the impact of these policies directly on the daily death rates as these policies aim to reduce the spread of the virus (i.e., lockdowns, testing, and contact tracing) and are not directly associated with reducing the daily death rate. Direct measures to reduce the daily death rates could be hospital resources, such as additional personnel, beds, ventilators, and intensive care facilities. ${ }^{11}$ However, given the positive association between aggregate daily cases and deaths, ${ }^{12}$ albeit with a lag between individual cases and resulting mortality, some inference can be made about the pattern of aggregate daily deaths given the pattern of aggregate daily cases, which we discuss briefly next.

\section{Results from overall policy response (strin- gency index) to flatten the curve}

Figure 1 shows the SI pattern, as computed by Hale et al., ${ }^{10}$ and confirmed daily new COVID-19 cases from January 1 to October 13, 2020. The February 22-23 containment and closure policies on the economy were the most powerful and eventually had an impact on reducing COVID-19 cases. Policies became more aggressive from February 23 until April 12, when the SI reached 93.5. Stringency policies were maintained at the highest level until May 3. Daily new cases were in decline since they peaked at 6557 on March 22, when the SI was one level less than its maximum at 91.7. Policies on containment and the closure of economic and social activities reduced the daily growth rate of confirmed cases. However, there was a lag period of approximately one month (February 23 until March 21) before reductions in new cases occurred. As stated above, strong policies on activities started on February 22-23 until May 3, while new cases rose until almost a month later (March 22) when they peaked. Bonacini et al. also found a delay in the impact of lockdown policies on cases. ${ }^{13}$

New daily cases continued to fall from the peak on March 22, and on May 4, many restrictions were relaxed, and the SI fell from 93.5 to 63. Stringency policies continued to have a downward trend, with the

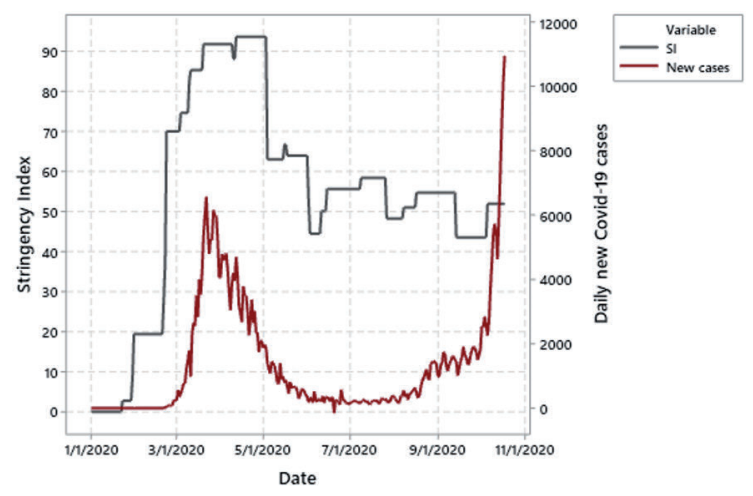

Figure 1. Stringency policies and daily new COVID-19 cases in Italy. The stringency index (SI) and cases are from the time series spreadsheet. $^{10}$ Dates as month/day/year. 
latest figure standing at 52 on October 13, 2020. As restrictions were lifted, new daily cases eventually started their ascent upwards, getting worse after Sep- tember. New COVID-19 cases on October 18 reached 10,925, surpassing the March 22 peak by approximately $66 \%$. As of October 20, 2020, Italy has

Table 1. Policy instruments according to Oxford COVID-19 Government Response Tracker (OxCGRT) stringency index version $8 .^{1}$

\begin{tabular}{|c|c|c|c|c|c|c|}
\hline Code & pol & $\begin{array}{l}\text { Date of first } \\
\text { licy enactment } \\
\quad(d / \mathbf{m} / \mathbf{y})\end{array}$ & $\begin{array}{c}\text { Possible } \\
\text { values }\end{array}$ & $\begin{array}{l}\text { Initially } \\
\text { assigned } \\
\text { value }\end{array}$ & $\begin{array}{c}\text { Value as of } \\
\text { October } 13,2020\end{array}$ & $\begin{array}{l}\text { Values } \\
\text { assigned }\end{array}$ \\
\hline $\mathrm{C} 1$ & School closure & $2 / 23 / 2020$ & $0-3$ & 3 & 0 & $\begin{array}{l}0=\text { no school closure } \\
1=\text { recommend closure or open with limitations } \\
2=\text { closure in certain regions or levels (e.g., just universities) } \\
3=\text { total school closure }\end{array}$ \\
\hline $\mathrm{C} 2$ & $\begin{array}{l}\text { Workplace } \\
\text { closures }\end{array}$ & $2 / 22 / 2020$ & $0-3$ & 3 & 2 & $\begin{aligned} 0= & \text { no workplace closure measures } \\
1= & \text { recommend closing or work from home. } \\
2= & \text { require closure or work from home for some workers or } \\
& \text { sectors } \\
3= & \text { require the closure of non-essential service and work } \\
& \text { from home }\end{aligned}$ \\
\hline $\mathrm{C} 3$ & $\begin{array}{l}\text { Cancel public } \\
\text { events }\end{array}$ & $2 / 23 / 2020$ & $0-2$ & 2 & 2 & $\begin{array}{l}0=\text { no cancellation } \\
1=\text { recommend cancellation } \\
2=\text { require cancellation of all public events }\end{array}$ \\
\hline $\mathrm{C} 4$ & $\begin{array}{l}\text { Restrictions } \\
\text { on gatherings }\end{array}$ & $2 / 23 / 2020$ & $0-4$ & 4 & 3 & $\begin{array}{l}0=\text { no restrictions } \\
1=\text { restrictions on huge gatherings (over } 1000 \text { people) } \\
2=\text { gathering restrictions between } 101-1000 \text { people } \\
3=\text { gathering restrictions between } 11-100 \text { people } \\
4=\text { gathering restrictions on } 10 \text { people or less }\end{array}$ \\
\hline C5 & $\begin{array}{l}\text { Close public } \\
\text { transport }\end{array}$ & $3 / 11 / 2020$ & $0-2$ & 1 & 1 & $\begin{aligned} 0= & \text { regular public transport schedule } \\
1= & \text { reduction of available routes, volume, and means of } \\
& \text { transportation } \\
2= & \text { closure of public transport }\end{aligned}$ \\
\hline C6 & $\begin{array}{l}\text { Stay-at-home } \\
\text { requirements }\end{array}$ & $2 / 23 / 2020$ & $0-3$ & 2 & 0 & $\begin{aligned} 0= & \text { no stay-at-home requirements } \\
1= & \text { recommend staying home } \\
2= & \text { leave home for essentials only (e.g., grocery) } \\
3= & \text { require to not leave home or with minimal exceptions } \\
& (\text { e.g., one person at a time, once a week) }\end{aligned}$ \\
\hline C7 & $\begin{array}{l}\text { Domestic } \\
\text { travel } \\
\text { restrictions }\end{array}$ & $2 / 22 / 2020$ & $0-2$ & 2 & 0 & $\begin{array}{l}0=\text { no restrictions } \\
1=\text { urge the general public not to move around } \\
2=\text { restrictions of movement }\end{array}$ \\
\hline $\mathrm{C} 8$ & $\begin{array}{l}\text { International } \\
\text { travel controls }\end{array}$ & $1 / 23 / 2020$ & $0-3$ & 1 & 3 & $\begin{array}{l}0=\text { no restrictions } \\
1=\text { screening arrivals } \\
2=\text { quarantine arrivals from high-risk regions } \\
3=\text { ban from some high-risk regions } \\
4=\text { total border closure }\end{array}$ \\
\hline H1 & $\begin{array}{l}\text { Public } \\
\text { information } \\
\text { campaigns }\end{array}$ & $1 / 31 / 2020$ & $0-2$ & 2 & 2 & $\begin{aligned} 0= & \text { no campaigns } \\
1= & \text { public officials urging caution about COVID- } 19 \\
2= & \text { coordinated public information campaign across } \\
& \text { traditional and social media }\end{aligned}$ \\
\hline $\mathrm{H} 2$ & Testing policy & $1 / 31 / 2020$ & $0-3$ & 1 & 2 & $\begin{aligned} 0= & \text { no testing policy } \\
1= & \text { only those who both (i) have symptoms AND } \\
& \text { (ii) meet specific criteria (e.g., key workers, admitted to } \\
& \text { hospital, came into contact with a known case, returned } \\
& \text { from overseas) } \\
2= & \text { testing of anyone showing COVID-19 symptoms } \\
3= & \text { open public testing }(e . g ., \text { drive through testing available } \\
& \text { to asymptomatic people) }\end{aligned}$ \\
\hline $\mathrm{H} 3$ & $\begin{array}{l}\text { Contact } \\
\text { tracing }\end{array}$ & $1 / 31 / 2020$ & $0-2$ & 2 & 1 & $\begin{array}{l}0=\text { no contact tracing } \\
1=\text { limited contact tracing; not done for all cases } \\
2=\text { comprehensive contact tracing; done for all identified cases }\end{array}$ \\
\hline
\end{tabular}

From Hale $e t$ al. ${ }^{10}$ summary of policies. Minor modifications were made to correct style, punctuations, and grammar; otherwise, the wording is verbatim. 
423,578 cases and 36,616 deaths, while on June 30, 2020 , total cases were $57 \%$ less at 240,760 cases and 34,788 deaths with the curve flattened out. Currently, cases are rising at a rate of over $2.5 \%$ per day, and if this rate continues, then in a month, there will be an expected one million infections.

Figure 2 shows a strong positive association between daily cases and deaths. Initially, as daily cases increased, daily deaths also increased, then both fell,

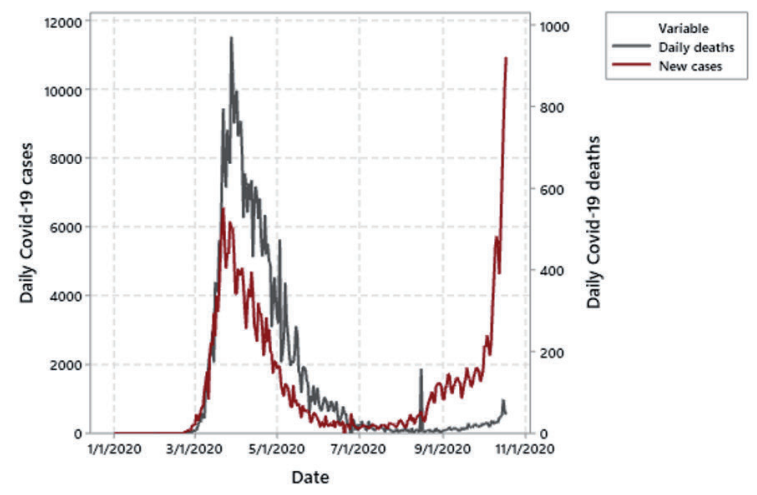

Figure 2. Daily COVID-19 cases and deaths in Italy. ${ }^{10}$ Dates as month/day/year. with daily deaths lagging behind. However, the recent increase in cases has not resulted in considerable increases in daily deaths, although there are signs of an upward trend in October with the exponential increase in cases. Why this decoupling between daily cases and deaths has occurred is currently a mystery but worth exploring in the future. Potential reasons could be that the initial COVID-19 deaths were mainly older male patients who also had other comorbidities, ${ }^{5,14}$ reducing the current pool of such vulnerable patients. Alternatively, people may be taking more precautions now than earlier on, or hospital resource allocation has increased over time, and the hospital staff is better prepared to treat patients.

\section{Specific policies responses to flatten the curve}

Table 1 and Figure 3 show the strength of each of the policies over this period. Italy started to screen international travelers on January 23. It increased the level of control to category 3 , banning travelers from high-risk regions after one week. On May 4, it reduced international travel restrictions (C8) to level 2, quarantining arrivals from such regions. International travel restrictions (C8) were removed for a short period of time from June 3 to 10 but then alternating between levels 2 and 3, where it currently stands.

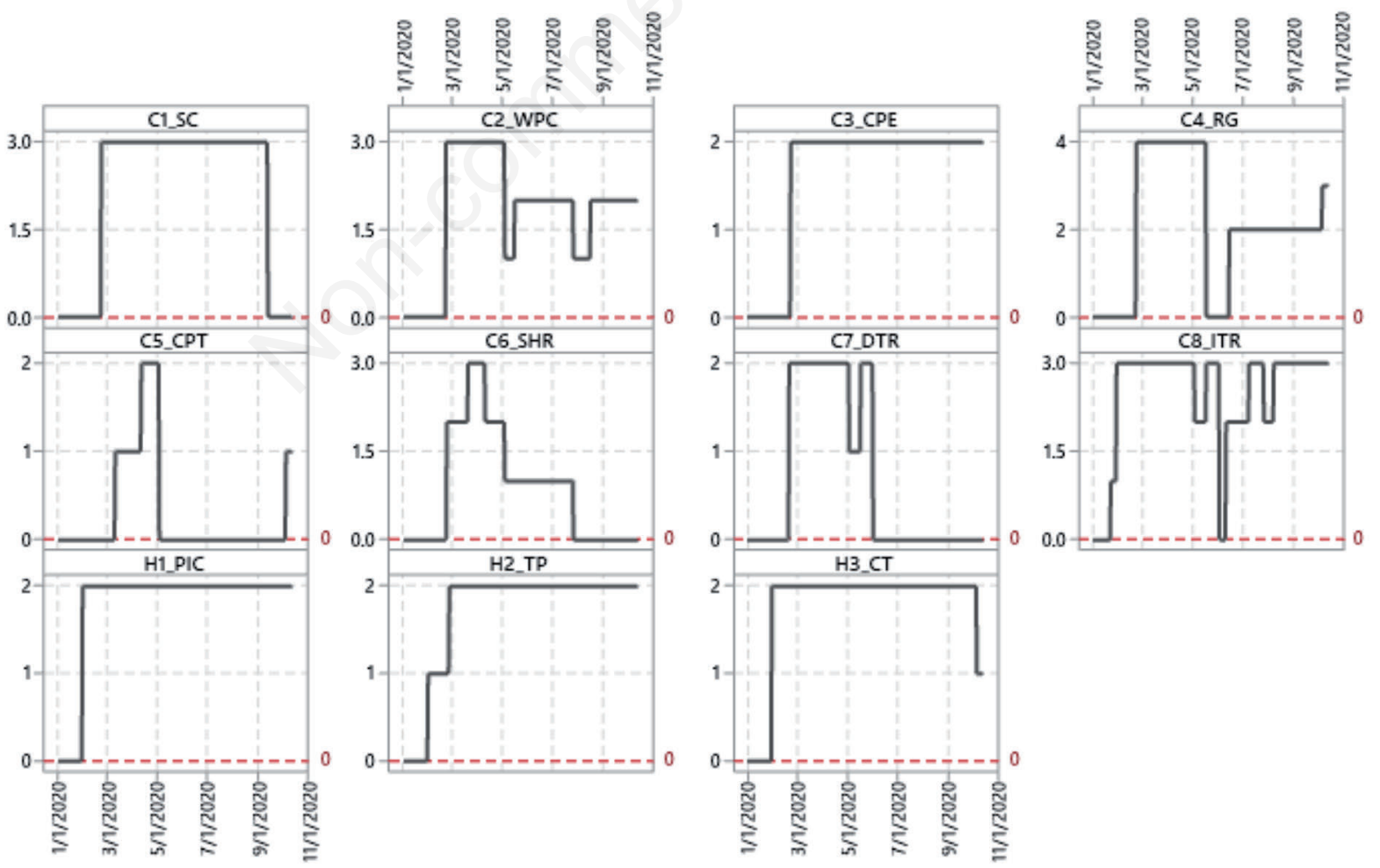

Figure 3. Policy paths on COVID-19 in Italy over time. C1-C8 and H1-3 refer to policies related to containment and closure policies as indicated by Hale et al. ${ }^{10}$ Source: https://www.bsg.ox.ac.uk/research/research-projects/coronavirus-government-response-tracker. Dates as month/day/year. 
On January 31, the Italian government enacted a public information campaign (H1) using traditional and social media communication channels to warn people of the pandemic and has been continuously in effect over this period. January 31 was also the enactment of policy to test people (H2) - although the exact conducted tests were not specified - but only for those showing symptoms and those who were either admitted to a hospital, arrived from overseas, or were key workers. This was raised to level 2, testing anyone showing COVID-19 symptoms on February 26, where it remained for the rest of the study period. The Italian authorities did not initiate level 3 whereby testing would be open to the public (e.g., drive-through testing facilities for asymptomatic people). It also conducted contact tracing (H3) for all confirmed cases starting January 31 . However, strangely, on October 6 , contact tracing dropped to level 1 , limiting contact tracing to a subset of identified cases. Hence, the first policies were enacted almost two months since China reported the first case on December 8, 2019 to WHO, which declared the COVID-19 outbreak a public health emergency of international concern on January $30 .{ }^{15,16}$ The above three health system policies coincide with the first three confirmed cases in Italy on January 31. No new cases were confirmed by the authorities until February 22, when 14 new cases were confirmed, increasing to 62 new cases on the next day and the start of the exponential rise in total COVID-19 cases in Italy. With the appearance of this seemingly unprecedented growth in cases, the government immediately, on February 22, ordered the closure of all workplaces except for essential services and working from homes (C2), and also imposed restrictions on domestic movements (C7) on February 21. On February 23 , the government took even more action and closed all schools $(\mathrm{C} 1)$, required the cancellation of all public events (C3), restricted gatherings to less than 10 people (C4), and required people to stay home except for essential travel or exercise (C6). The last policy to be enacted was on March 11, reducing public transportation routes and volume (C5). The WHO declared COVID-19 a pandemic on March 11.

As stated earlier, policies rose in strength, but since May 4, all containment and closure policies have been lax except for the cancellation of public events (C3), which still is at its highest level. Workplace closure (C2) was reduced to level 2, with some intermittent periods to level 1. Public transportation restrictions (C5) were eliminated on May 4 but, on October 6, stringency increased to level 1 , reducing routes and volume. The stay-at-home stringency policy (C6) was reduced slowly and eventually eliminated: C6 was dropped to level 2 from the highest level 3 on April 10, to level 1 on May 4, and on July 27, stay-at-home measures were dropped until the end of this observational period. Do- mestic travel restrictions (C7) were removed on June 2. Restrictions on gatherings (C4) of less than 10 people were at the highest level 4 until May 18 when they were eliminated only to increase again to level 2 on June 15, and on October 6, they were raised again to level 3. Finally, school closure (C1) was kept at level 3, with all schools shut down until September 14, when schools were allowed to reopen. The reopening of schools seems to be the main culprit of the recent exponential rise in COVID-19 cases in conjunction with no stay-athome restrictions, domestic travel restrictions, and reduced contact tracing.

\section{Conclusions}

This review provides an overview of how the COVID-19 pandemic evolved in Italy, and shows the importance that policies played in containing its spread initially after maximum SI was achieved on April 12. However, the delay in the enactment of policies with the substantial initial growth of cases caused policies to lag behind infections. Restrictions were relaxed, causing the SI to fall from 93.5 to 63 in May and then again to 52 in October. The curve flattened between June and August. The relaxation of policies, especially those related to school reopening, no stayathome and domestic travel restrictions, and reduced contact tracing, are the likely causes for the resurgence of COVID-19 in Italy towards the end of September. One of the main reasons for the spike in September and October seems to have been the reopening of schools, and perhaps authorities should have heeded the concerns by educational specialists in June. ${ }^{17}$ This study is observational, but its findings are in line with those of Giordano et al., ${ }^{2}$ who modeled Italy's COVID-19 epidemic under eight stages of infection and examined population-wide interventions. They demonstrated that restrictions on gatherings such as social distancing, widespread testing, and contact tracing can stop Italy's ongoing COVID-19 pandemic. The observed experience in Italy shows how difficult it is to contain COVID-19 if policies are reactive rather than pro-active, and it is made more complicated by the socio-economic and structural or organizational challenges facing the pandemic in Italy. ${ }^{18}$

\section{References}

1. Lazzerini M, Putoto G. COVID-19 in Italy: momentous decisions and many uncertainties. Lancet Glob Health 2020;8:e641-2.

2. Giordano G, Blanchini F, Bruno R, et al. Modelling the COVID-19 epidemic and implementation of populationwide interventions in Italy. Nat Med 2020;26:855-60.

3. JHU (John Hopkins University). COVID-19 Dashboard by the Center for Systems Science and Engineering 
(CSSE) at Johns Hopkins University; 2020. Available from: https://coronavirus.jhu.edu/map.html (last accessed: October 22, 2020)

4. Grossi U, Zanus G, Felice C. Coronavirus disease 2019 in Italy: The Veneto model. Infect Control Hosp Epidemiol 2020;1-2. doi: 10.1017/ice.2020.225. [Epub ahead of print].

5. Onder G, Rezza G, Brusaferro S. Case-fatality rate and characteristics of patients dying in relation to COVID19 in Italy. JAMA 2020;323:1775-76. Erratum: JAMA 2020;323:1619.

6. Vicentini C, Bordino V, Gardois P, Zotti CM. Early assessment of the impact of mitigation measures on the COVID-19 outbreak in Italy. Public Health 2020;185:99101.

7. IMF (International Monetary Fund). World Economic Outlook, April 2020: The Great Lockdown; April 14, 2020. Available from: https://www.imf.org/en/Publications/WEO/Issues/2020/04/14/weo-april-2020 Accessed: October 22, 2020.

8. IMF (International Monetary Fund). World Economic Outlook, October 2020: A Long and Difficult Ascent; October 7, 2020. Available from: https://www.imf.org/en/ Publications/WEO/Issues/2020/09/30/world-economicoutlook-october-2020 Accessed: October 22, 2020.

9. McKee M, Stuckler D. If the world fails to protect the economy, COVID-19 will damage health not just now but also in the future. Nat Med 2020;26:640-2.

10. Hale T, Webster S, Petherick A, et al. Oxford COVID-19 Government Response Tracker. Blavatnik School of Government, Oxford University. 2020. Available from: https:// www.bsg. ox.ac.uk/COVIDtracker; https://www.bsg.ox. ac.uk/research/research-projects/coronavirus-government-response-tracker Accessed: October 22, 2020.
11. Remuzzi A, Remuzzi G. COVID-19 and Italy: what next? Lancet. 2020;395:1225-8.

12. Rubino S, Kelvin N, Bermejo-Martin JF, Kelvin D. As COVID-19 cases, deaths and fatality rates surge in Italy, underlying causes require investigation. J Infect Dev Countries 2020;14:265-7.

13. Bonacini L, Gallo G, Patriarca F. Identifying policy challenges of COVID-19 in hardly reliable data and judging the success of lockdown measures. J Popul Econ 2021;34:275-301.

14. Palmieri L, Vanacore N, Donfrancesco C, et al. Italian National Institute of Health COVID-19 Mortality Group. Clinical characteristics of hospitalized individuals dying with COVID-19 by age group in Italy. J Gerontol A Biol Sci Med Sci 2020;75:1796-800.

15. The Guardian. First COVID-19 case happened in November, China government records show - report; March 13, 2020. Available from: https://www.theguardian.com/world/2020/mar/13/first-COVID-19case-happened-in-november-china-government-recordsshow-report Accessed: October 22, 2020.

16. Think Global Health. Updated: Timeline of the coronavirus; 2020. Available from: https://www.thinkglobalhealth.org/article/updated-timeline-coronavirus Accessed: October 22, 2020.

17. Forbes. Protests in Italy over strategy to reopen schools in September; June 28, 2020. Available from: https://www.forbes.com/sites/irenedominioni/2020/06/2 8/protests-in-italy-over-strategy-to-reopen-schools-inseptember/ Accessed: October 22, 2020.

18. Nardini S, Sanguinetti CM, De Benedetto F, et al. SARS$\mathrm{CoV}-2$ pandemic in Italy: ethical and organizational considerations. Multidiscip Respir Med 2020;15:672. 